\title{
Investigating Anxiety in an Indonesian EFL Speaking Classroom
}

\author{
Rais Abin \\ raisabin43@yahoo.com \\ Hariadi Syam \\ haryadisyam@gmail.com
}

Universitas SembilanBelas November

\begin{abstract}
This research aimed to explore the kinds of anxiety experienced by the students in learning speaking, and to examine the causes of the anxiety in learning speaking. This research employed descriptive qualitative method. The subjects of this research were 36 students consisting 19 females and 17 males selected to be research participants through conveniently selected sampling. The data of this research were collected by online questionnaire, and interview. The obtained data were analyzed in three major phases namely data reduction, data display, and conclusion. The result of the research revealed three kinds of anxiety experienced by the students in learning speaking namely trait anxiety, situational-specific anxiety, and state anxiety. Furthermore, the causes of speaking anxiety were communication apprehension, test anxiety, and fear of negative evaluation.
\end{abstract}

Keyword : Anxiety, EFL Classroom, Speaking

\section{INTRODUCTION}

In learning language, affective factor has been considered as one of crucial factors. This view is in line with the Zare and Riasati (2012) who stated that language practitioners started studying affective factors more deeply in language pedagogy. One of the affective factors which has been widely explored is learning anxiety. Anxiety is defined as tension, apprehension, and nervousness feeling related to autonomic nervous system (Horwitz \& Cope,1986). Furthermore, Gardener \& MacIntyre (1991) claimed that language anxiety is the apprehension experienced by students when they are required to use the foreign language.

Many language researchers claimed that anxiety may serve as affective filter preventing students from achieving a high level of proficiency in foreign language. The previous researches revealed that anxiety is one of the most crucial affective factors affecting foreign language learning (Spielman and Radnofsky: 
2001; Chen \& Chang: 2004; Na: 2007; Brown: 2007; Lucas: 2011). The statement is also supported by Brown (2000) who stated that anxiety, dealing with feelings of being uncomfortable, frustrated, apprehensive, or worried, cause a crucial affective role in language learning.

The negative relationship between anxiety and language learning has been consistently identified since Horwitz \& Cope (1986) introduced and specified the term called foreign language anxiety. According to Gardener \& MacIntyre (1991), foreign language anxiety can lead various problems for foreign language students since it can influence the acquisition, retention, and production of the new language. In other words, the anxious students in the language classroom will experience negative result in language leaning compared with more relaxed classmates.

Many factors can trigger a student to experience feeling of learning anxiety. According to Marwan (2007) lack of confidence, lack of preparation, and fear of failing the class are the main causes of anxiety. He also added that the students who experience learning anxiety will consider all the acts to show in a foreign language as a threat to their self perception. Meanwhile, Zhang \& Zhong (2012) stated that the possible causes of foreign language anxiety are various, such as learner-induced anxiety, skill-specific anxiety, classroom-related anxiety, and society-imposed anxiety Thornburry (2005) believed that some factors influenced to speaking failure and sense of anxiety, such as lack of vocabularies, improper grammatical, fears of mistakes.

In Indonesia, English is started to be taught in junior high schools. However, due to a limited amount of exposure to English, opportunities to practice their foreign language skills only take place in the classroom. Therefore, it cannot be denied that if several students admit that they only learn the foreign language as one of the school requirements.

\section{LITERATURE OF REVIEW}

To understand clearly the concept of language anxiety, MacIntyre and Gardner (1991) indentified three types of anxiety, namely trait anxiety (a personality trait), state anxiety (an emotional state), and situation specific anxiety (anxiety in a well-defined situation).

Woodrow (2006) considered trait anxiety is a relatively stable personality trait. A person who is experiences this anxiety is likely to feel anxious in a variety of situations. Furthermore, state anxiety, on the other hand, is a temporary condition experienced at particular moment. Meanwhile, situation specific anxiety reflects a trait that recurs in specific situations.

Those kinds of anxiety are triggered with different causes. According to Horwitz \& Cope (1986) students or learners may experience anxiety because of communication apprehension, test anxiety, and fear of negative evaluation. Furthermore, Worde (2003) claimed that there are five causes of language anxiety, such as non comprehension, speaking activity, pedagogical and instructional practices, error corrections, and native speakers. This claim is in line 
with Liu (2007) who considered nine factors affecting students' anxiety, they were lack of vocabulary, low English proficiency, lack of preparation, lack of practice, fear of making mistakes and being laughed at, fear of losing face, fear of being focus of attention, fear of unable to follow and understand others, and the last inability to express ideas.

\section{METHOD}

This research employed descriptive qualitative research design. There were 36 students consisting 19 females and 17 males selected to be research participants through conveniently selected sampling. Besides, there were two instruments used in this research namely online questionnaire and interview. The research data were collected in three steps namely observing, recording, and transcribing. Furthermore, the data were analyzed covering three important activities namely data reduction, data display, and conclusion based on Miles and Huberman (1994).

\section{RESULT AND DISCUSSIONS}

There were three types of anxiety experienced by the students in EFL classroom communication during speaking activities such as trait anxiety, situational-specific anxiety, and state anxiety. Each type of the anxiety was experienced by the students in EFL classroom was triggered by different causes.

The first type of anxiety revealed in learning speaking was trait anxiety. In this case, the anxiety was experienced by the students. The students were feeling anxious while giving speech in English. They were anxious if they made a mistake. They were also anxious because they had lack of vocabulary.

a. Trait Anxiety

\begin{tabular}{|c|c|c|c|c|c|c|}
\hline $\mathbf{N}$ & Statement & $\begin{array}{c}\text { Levels of } \\
\text { Agreement }\end{array}$ & $\begin{array}{l}\text { Freq } \\
\text { uenc } \\
\text { y }\end{array}$ & $\begin{array}{l}\text { Percentag } \\
\text { e }\end{array}$ & $\begin{array}{l}\text { Mea } \\
\text { n }\end{array}$ & $\begin{array}{l}\text { Descriptio } \\
\text { n }\end{array}$ \\
\hline 1 & $\begin{array}{l}\text { I feel anxious } \\
\text { because I } \\
\text { have lack of } \\
\text { vocabularies }\end{array}$ & $\begin{array}{l}\text { Strongly Agree } \\
\text { Agree } \\
\text { Neutral } \\
\text { Disagree } \\
\text { Strongly } \\
\text { Disagree }\end{array}$ & $\begin{array}{c}4 \\
22 \\
8 \\
2 \\
0\end{array}$ & $\begin{array}{l}11,1 \% \\
61,1 \% \\
22 \% \\
5,6 \% \\
0 \%\end{array}$ & 3,7 & Agree \\
\hline
\end{tabular}

Based on the table above, it can be seen that there were 4 or $11,1 \%$ students strongly agreed if they were anxious in speaking English because they had lack of vocabularies, 22 or of $61,1 \%$ students agreed, 8 or $22 \%$ students were neutral, 2 or $5,6 \%$ students disagreed, and no students or $0 \%$ strongly disagreed with the statement. Therefore, the mean value of this statement was 3.7 describing "agree". It means that the students felt anxious because they had lack of 
vocabularies. It is in line with what the students stated when they were interviewed.

The researcher : Irma sering merasa cemas nanti salah itu karena apa? Karena tidak tahu atau kurang kosakatanya? (Irma, why do you often feel anxious?

Student 8 : kosakata saya kurang sekali mam (I am poor in vocabulary, mam)

It can be seen on the interview script above, the students experienced an anxiety due to lack of vocabulary. Furthermore, the anxiety appeared because of communication apprehension factor. In this case, the student felt nervous since he had lack of confidence to speak English caused by limited vocabulary. Therefore, it can be concluded that the student experienced trait anxiety.

b. Situation-Specific Anxiety

\begin{tabular}{|l|l|l|l|l|l|l|}
\hline $\mathbf{N}$ & Statement & \multicolumn{1}{|c|}{$\begin{array}{c}\text { Levels of } \\
\text { Agreement }\end{array}$} & $\begin{array}{l}\text { Freq } \\
\text { uenc } \\
\mathbf{y}\end{array}$ & $\begin{array}{l}\text { Percentag } \\
\text { e }\end{array}$ & $\begin{array}{l}\text { Mea } \\
\text { n }\end{array}$ & $\begin{array}{l}\text { Descriptio } \\
\text { n }\end{array}$ \\
\hline \multirow{8}{*}{8} & I feel nervous & Strongly Agree & 3 & $8,3 \%$ & & \\
& when I have & Agree & 20 & $55,6 \%$ & & \\
& to speak & Neutral & 5 & $13,9 \%$ & 3,5 & Agree \\
& English & Disagree & 8 & $22,2 \%$ & & \\
& without & Strongly & 0 & $0 \%$ & & \\
preparation & Disagree & & & & \\
\hline
\end{tabular}

Based on the table above, it can be seen that 3 or $8,3 \%$ students strongly agreed that they felt anxious when they had to speak English without preparation. 20 or $55,6 \%$ students agreed, 5 or $13,9 \%$ students was neutral, 8 or $22,2 \%$ students disagreed and none of the students strongly disagreed with the statement. Furthermore, the mean value of this statement was 3.4 describing "agree". This description was supported by the result of interview done by the researcher below:

The researcher : Bagaimana perasaanmu ketika kamu harus berbicara bahasa Inggris tanpa persiapan? (how do you feel when you have to speak $\mathrm{f}$ English without preparation?)

Student 1 : eh.. takut.. cemas (eh.. scared.. anxious)

Student 2 : takut, malu, takut salah (scared, shy, scared I pronounce words wrongly )

c. State Anxiety

\begin{tabular}{|c|c|c|c|c|c|c|}
\hline $\begin{array}{l}\mathbf{N} \\
\mathbf{0}\end{array}$ & Statement & $\begin{array}{c}\text { Levels of } \\
\text { Agreement }\end{array}$ & $\begin{array}{l}\text { Freq } \\
\text { uenc } \\
\text { y }\end{array}$ & $\begin{array}{l}\text { Percentag } \\
\text { e }\end{array}$ & $\begin{array}{l}\text { Mea } \\
\text { n }\end{array}$ & $\begin{array}{l}\text { Descriptio } \\
\text { n }\end{array}$ \\
\hline 14 & $\begin{array}{l}\text { I feel anxious } \\
\text { because my }\end{array}$ & $\begin{array}{l}\text { Strongly Agree } \\
\text { Agree }\end{array}$ & $\begin{array}{c}7 \\
14\end{array}$ & $\begin{array}{l}19,4 \% \\
38,9 \%\end{array}$ & & \\
\hline
\end{tabular}




\begin{tabular}{|l|l|l|l|l|l|}
\hline friends will & Neutral & 4 & $11,1 \%$ & 3,3 & Neutral \\
laughed at me & Disagree & 8 & $22,2 \%$ & & \\
if I make & Strongly & 3 & $8,3 \%$ & & \\
mistakes & Disagree & & & & \\
\hline
\end{tabular}

Based on the table above, it can be identified that 7 or $19,4 \%$ students strongly agreed that they felt anxious because their friends would laugh at them if they made mistake in speaking English. 14 or 38,9\% students agreed, 4 or $11,1 \%$ students was neutral, 8 or $22,2 \%$ students disagreed and 3 or $8,3 \%$ students strongly disagreed with the statement. Furthermore, the mean value of this statement was 3.3 describing "neutral". This description was supported by the result of interview done by the researcher below:

The researcher : Kenapa kamu takut berbicara di depan kelas? (Why do you feel anxious to speak in front of the class?

Student 1 : karena takut salah, kalau salah ditertawakan (because I am scared if my friend laughed at my English mistakes)

Student 3 : karena.. karena.. malu (because... because... I am shy)

Dealing with the script above, it can be seen that the students experience state anxiety. In this case, they were anxious to speak English because they felt shy if their classmates laughed at them due to their speaking mistakes. On the other words the cause of the students' anxiety is fear of negative evaluation since the responses of other students led them anxious to speak English.

\section{Discussion}

Based on the previous analysis, the researcher found that there were three kinds of anxiety experienced by the students in learning speaking. They were trait anxiety, situational-specific anxiety, and state anxiety.

Trait anxiety was experienced by the students since they had lack of vocabularies. The finding is in line with Liu (2007) who stated that student feel anxious to speak the foreign language due to the limited amount of vocabulary that they have to express their ideas and views. Furthermore, situational specific anxiety attributed the students 'anxiety to being not prepared. They also claimed that they felt less anxious and more confident to speak English with preparation. However, some students also admitted that they were anxious only in front of the class. These statements supported Liu (2007) stating that says if the student is well-prepared, he will be more ready to engage in classroom communication. Lastly, state anxiety was experienced by the students in learning speaking since they felt anxious they were giving an English speech. They were also anxious if they made a mistake in speaking. In addition, they felt anxious due to lack of vocabulary. It means that the students experienced a combination of trait and situation-specific anxiety. 
Meanwhile, dealing with causes of anxiety in speaking English, it was revealed three causes of anxiety. They were communication apprehension, test anxiety, and fear of negative evaluation. This finding is line with Zhang \& Zhong (2012) who claimed that anxiety possibly appeared due to learner-induced anxiety may result from learners' erroneous beliefs, unrealistic high standards, poor language abilities, self-perceived incompetence, inclined competitive nature and dispositional fear of negative evaluation.

\section{CONCLUSIONS, IMPLICATION, AND SUGGESTIONS}

Two important points can be drawn as conclusion. The first, there were three kinds of anxiety experienced by the students in learning speaking namely trait anxiety, situational-specific anxiety, and state anxiety. The anxieties were experienced by the students in learning speaking in different reasons, such as communication apprehension, test anxiety, and fear of negative evaluation.

As suggestion, the result of this research can motivate the teachers to facilitate the students in learning speaking to minimize the students' anxiety for optimal output in learning process. In addition, the next researches are also expected to explore the students' anxiety in different skills of English.

\section{REFERENCES}

Brown, H. (2000). Principles of Language Learning and Teaching. New Jersey: Prentice Hall.

Chen, T., \& Chang, G. (2004). The Relationship between Foreign Language Anxiety and Learning Difficulties. Foreign Language Annals, 37(2), 279289. doi: 10.1111/j.1944-9720.2004.tb02200.x

Horwitz, E., Horwitz, M., \& Cope, J. (1986). Foreign Language Classroom Anxiety. The Modern Language Journal, 70(2), 125-132. doi: 10.1111/j.1540-4781.1986.tb05256.x

Liu, M. (2007). Anxiety in Oral English Classrooms: A Case Study in China. Indonesian Journal of English Language Teaching, Vol 3, No. 1.

Lucas, R., Miraflores, E., \& Go, D. (2011). English Language Learning Anxiety among Foreign Language Learners in the Philippines. Philippine ESL Journal, Vol. 7, July 2011(1718-2298).

Macintyre, P., \& Gardner, R. (1991). Investigating Language Class Anxiety Using the Focused Essay Technique. The Modern Language Journal, 75(3), 296-304. doi: 10.1111/j.1540-4781.1991.tb05358.x 
Marwan, A. (2007). Investigating Students' Foreign Language Anxiety. Malaysian Journal Of ELT Research, Vol.3(ISSN: 1511-8002).

Miles, A., \& Huberman, A. (1994). Qualitative Data Analysis $2^{\text {nd }}$ Edition. London. SAGE Publications.

Na, Z. (2007). A Study of High School Students' English Learning Anxiety. The Asian EFL Journal, Volume 9, Number 3(1738-1460).

Spielmann, G., \& Radnofsky, M. (2001). Learning Language under Tension: New Directions from a Qualitative Study. The Modern Language Journal, 85(2), 259-278. doi: 10.1111/0026-7902.00108

Thornbury, S. (2005). How to Teach Speaking. England: Pearson Education Limited.

Woodrow, L. (2006). Anxiety and Speaking English as a Second Language. RELC Journal, 37(3), 308-328. doi: 10.1177/0033688206071315

Worde, R. (2003). Students' perspectives on foreign language anxiety. Retrieved 6 October 2019, from http://www.vccaedu.org/inquiry/inquiryspring2003/i-81-worde.html

Zare, P., \& Riasati, J. (2012). The Relationship between Language Learning Anxiety, Self-Esteem, and Academic Level among Iranian EFL Learners. Pertanika J. Soc. Sci. \& Hum., (0128-7702), 219 - 225.

Zhang, R., \& Zhong, J. (2012). The Hindrance of Doubt: Causes of Language Anxiety. International Journal Of English Linguistics, 2(3). doi: 